\title{
Motives and modes of FDI in Poland: An exploratory qualitative study ${ }^{*}$
}

\author{
Marian Gorynia, Jan Nowak, Radoslaw Wolniak ${ }^{* *}$
}

The present paper is based on a complex analysis of the results from a survey of seven subsidiaries of multinational corporations (MNCs), which entered the Polish market in the early nineties, and focuses on the motives and modes of setting up these subsidiaries. The survey design has been based on an extensive literature review and the collected data are analysed using a within-case and cross-case approach. The findings of this exploratory study lead to the formulation of pertinent hypotheses that may serve as possible guidelines for undertaking and stimulating future research based on larger and more representative samples of MNC subsidiaries.

Dieser Beitrag basiert auf einer komplexen Analyse von Resultaten einer Umfrage von sieben Niederlassungen multinationaler Unternehmungen (MNCs), die in den frühen neunziger Jahren in den polnischen Markt eintraten, und konzentriert sich auf die Motivation und den Modellen der Gestaltung dieser Niederlassungen. Die Umfragegestaltung basierte auf einer ausführlichen Literaturrecherche und die gesammelten Daten wurden mithilfe der Within-Case und Cross-Case Ansätze analysiert. Die Ergebnisse dieser ersten Studie führen zur Formulierung einschlägiger Hypothesen, die als mögliche Richtlinien für die Ausgestaltung und Anregung zukünftiger, auf größeren und repräsentativeren Stichproben von MNCs basierender, Forschung dienen könnten.

Keywords: motives for FDI, modes of FDI, transition economy, FDI in Poland

Manuscript received:05.08.05, accepted:24.01.06 (2 revisions)

** Marian Gorynia, Prof., Poznan University of Economics. Main research areas: International business, strategic management and firms' strategies during transition. Corresponding address: m.gorynia@ae.poznan.pl

Jan Nowak, Prof., Central European University Business School, Budapest. Main research areas: International business and marketing. Corresponding address: nowakj@ceubusiness.com

Radoslaw Wolniak, Senior Lecturer, Warsaw University. Main research areas: International business and international marketing. Corresponding address: wolniak@coin.wne.uw.edu.pl 


\section{Introduction}

Foreign direct investment (FDI) has played a pivotal role in the transformation of post-communist economies of Central and Eastern Europe (CEE) for more than a decade now. This is especially true for Poland which experienced a phenomenal growth of inward FDI. The analysis of inflow of FDI into Poland since the beginning of the transformation process reveals an uninterrupted increase in the inflow until 2001 when the first decline occurred (by almost 40 percent), followed by the second decline in 2002 on a smaller scale. It is worth noting that these declines were consistent with observed world-wide trends (UNCTAD 2003). The growth resumed in the subsequent years and FDI flows into Poland reached a record level of 12.9 billion in 2004 (UNCTAD 2006).

Poland remains one of the top FDI destinations in CEE, although the rank of Poland turns out to be different when FDI stock per capita is considered (Poland occupies the $7^{\text {th }}$ position in this respect). Four countries dominate as foreign investors in Poland - France, USA, Germany and the Netherlands. In 2002, when the primary research for this paper was conducted, these four countries jointly accounted for more than 50 percent of the total FDI stock in Poland (see Table 1). Through establishing their subsidiaries in the Polish market, firms from these four and other investor countries were instrumental in transforming failing state-owned firms into viable operations or in creating new enterprises, thus restructuring, modernising and generally changing the structure of entire industries. The investment modes used included acquisitions, green-field investments and joint venture operations.

Data documenting investment mode choice in Poland are scarce, fragmentary and often based on estimates. According to these data, in 1990 only approx. 3\% of foreign direct investment projects in Poland were undertaken through greenfield operations, acquiring for that purpose 127 hectares of land. But already in 1992 approx. 35\% of the total value of FDI stock was allocated through the said green-field mode (Wolniak 1993). This illustrates the intensity of the drive towards the green-field entry mode in the early years of the transformation process to the market led system. In 2000 green-field FDI were dominant with a share of $65 \%$ of the annual FDI inflow, mainly due to the diminishing pool of available acquisition targets via privatisation of state owned firms (Durka et al. 2001). The Polish Information and Foreign Investment Agency (known under the Polish acronym as PAIiIZ) indicated that over 50\% of FDI inflows in 2003 were accounted for by green-field investments (PAIiIZ 2004).

- Many factors have influenced the decision to invest and the choice of a given mode of investment. In turn, FDI motives and modes have had important implications for the subsidiary characteristics and performance.

- The present study sets out to investigate the motives for undertaking foreign investment and modes of executing this investment, using data 
collected from seven foreign subsidiaries of multinational corporations (MNCs) operating in Poland. The principal research purpose is to determine what motivated these identified foreign investors to enter the Polish market, what factors determined their choice of FDI mode, and what patterns emerged in the relationships between these motives and modes.

Table 1. Stock of FDI in Poland by 15 largest countries of origin as of June 30, 2002

\begin{tabular}{|l|l|c|c|c|}
\hline No & Country & $\begin{array}{c}\text { Capital Invested } \\
\text { (USD million) }\end{array}$ & $\begin{array}{c}\text { Investment Plans } \\
\text { (USD million) }\end{array}$ & $\begin{array}{c}\text { Number of } \\
\text { companies }\end{array}$ \\
\hline 1 & France & $11,503.0$ & $1,975.5$ & 89 \\
\hline 2 & USA & $7,985.2$ & $2,389.0$ & 126 \\
\hline 3 & Germany & $7,444.6$ & $1,290.9$ & 212 \\
\hline 4 & The Netherlands & $4,976.1$ & 563.7 & 76 \\
\hline 5 & Italy & $3,701.1$ & $1,272.7$ & 59 \\
\hline 7 & Great Britain & $2,899.1$ & 349.5 & 40 \\
\hline 8 & International & $2,803.3$ & 913.5 & 57 \\
\hline 9 & Sweden & $2,653.7$ & 963.8 & 23 \\
\hline 10 & Belgium & $1,649.1$ & 127.0 & 38 \\
\hline 11 & Korea & $1,621.8$ & 20.0 & 2 \\
\hline 12 & Denmark & $1,331.0$ & 241.5 & 1 \\
\hline 13 & Russia & $1,286.4$ & 301.0 & 21 \\
\hline 14 & Ireland & $1,039.7$ & $\mathrm{~N} / \mathrm{A}$ & \\
\hline 15 & Cyprus & 911.7 & 175.0 & \\
\hline $\begin{array}{l}\text { Total investment over USD } 1 \\
\text { million (all countries) }\end{array}$ & 904.7 & 338.5 & \\
\hline $\begin{array}{l}\text { Estimated investment under USD } \\
1 \text { million (all countries) }\end{array}$ & $57,610.3$ & & $12,323.3$ & \\
\hline Total (all countries) & $3,990.1$ & & \\
\hline
\end{tabular}

Note: Although data on FDI stock are now available for more recent years, the 2002 year data correspond to the time frame of the primary research conducted for this paper

Source: PAIiIZ 2003.

The first part of the study summarises an extensive literature review on the subject of FDI motives and modes. This literature review leads to a research methodology section where the authors describe their approach to data collection and analysis. In the subsequent sections individual cases are outlined, cross-case analysis is conducted and hypotheses regarding the motives, modes and the relationship between the two are formulated. In the concluding section, the authors summarise the main finding of the case analyses and show how the present study provides guidance and direction for further research based on larger and more representative samples of foreign MNC subsidiaries operating in Poland. 


\section{Motives and modes of FDI - literature review}

\section{Motives for FDI}

The reasons prompting firms to undertake FDI have inspired and absorbed international business scholars for four decades now. These reasons have been part and parcel of various theories and paradigms of international production. ${ }^{1}$ According to Dunning (1993/1998), four groups of motives for FDI can be distinguished:

- Resource seeking,

- Market seeking,

- Efficiency seeking and

- Strategic asset seeking.

The resource-seeking firms are motivated to invest abroad to acquire specific resources at a lower cost than could be obtained in their home country, if these resources were obtainable at all. Dunning distinguishes three types of resource seekers: (a) those seeking physical resources (such as raw materials and agricultural products); (b) those seeking cheap and well motivated unskilled or semi-skilled labour: and (c) those seeking technological capacity, management or marketing expertise and organisational skills (Dunning, 1993).

Market seekers are firms that invest in a particular country or region in order to serve markets in this country or region. Apart from market size and expected market growth, there are four main reasons for which market-seeking firms may undertake foreign investment, namely: (a) a firm's main suppliers or customers may have expanded overseas and in order to retain its business, the firm needs to follow them; (b) a firm may need to adapt its product to local tastes and specific market requirements, which can only be achieved through market presence in the form of FDI; (c) production and transaction costs of serving a local market from an adjacent facility may be lower than when supplying that market from a distance and (d) a firm may consider it necessary, as part of its global strategy, to have a physical presence in the leading markets served by its competitors. Unlike other types of foreign direct investors, market-seeking firms tend to treat their foreign affiliates as self-contained business units rather than as part of an integrated chain of value adding activities (Dunning 1993).

1 Developed by such scholars as S.H. Hymer, P.J. Buckley, M.C. Casson, J.F. Hennart, A.M. Rugman, D.J. Teece, R. Vernon, L.T. Wells, R.E. Caves, T. Horst, H. Johnson, S.P. Magee, B. Swedenborg, T.A. Pugel, A.L. Calvet, R.F. Owen, S. Lall, N.S. Siddhathan, N. Kumar, F.T. Knickerbocker, E.M. Graham, E.B. Flowers and J.H. Dunning. A summary of international production theories can be found, e.g., in Dunning (2001) and Hennart (2001). 
The motivation of efficiency seeking foreign direct investors is to rationalise their production, distribution and marketing activities through common governance of and synergy-building among geographically dispersed operations. Such rationalisation essentially stems from two sources: the advantages of differences in the cost of factor endowments between countries and the economies of scale and scope (Dunning 1993).

The strategic asset seekers are those firms which engage in FDI to promote their strategic objectives - usually that of sustaining or enhancing their international competitiveness. Similarly to the efficiency seeking firms, the strategic asset seekers aim to capitalise on the advantages of the common ownership of a network of activities and capabilities in diverse environments (Dunning 1993).

Dunning argues that the former two motives (resource and market seeking) typically characterise initial FDI, while the latter (efficiency and strategic asset seeking) characterise sequential FDI. He also argues that [...] "as strategic assetacquiring investment has become more important, the locational needs of corporations have shifted from those to do with access to markets, or to natural resources, to those to do with access to knowledge-intensive assets and learning experiences, which augment their existing O specific advantages" (Dunning, 1998).

While the motives for FDI have been extensively discussed in the literature, only few empirical studies can be identified which deal specifically with the motives for FDI in Central and Eastern Europe (CEE). The study of Ali and Mirza (1996), analysed market entry strategies of UK firms in Poland. Among other issues, these authors present UK firms' motives for entering the Polish market. The motives given by the respondents as being the most important for investing in Poland included: to capitalise on Poland's strategic location; to obtain higher profits; to penetrate markets; to pre-empt competitors and to establish a local image. Somewhat unexpectedly, the motive that is often heralded as the most important in descriptive studies of FDI in CEE (Hardy 1994), lower labour costs, was in the middle of the said authors' ranking scale. Altzinger's study of Austrian FDI in CEE (Altzinger 1998) shows the overwhelming importance of market-driven motives.

Only a few of the surveyed sectors (the so-called core industrial sectors such as metals, mechanical products, and electrical and electronic equipment) were mostly motivated by low wage costs. The predominance of market-driven motives was confirmed by sales patters of the affiliates, which were selling a bulk of their products on local markets. Fahy, Shipley, Egan and Neale (1998), examined the motives and experiences of British firms establishing joint ventures in Hungary. The results of their study revealed that the country's stable economic environment and the potential of its market were the primary reasons why the said firms invested in Hungary. The study of Marinova and Marinov (2003) was based on a mail survey and personal interviews conducted among 
foreign investors in Bulgaria, Hungary, Poland and Slovenia. The results of this study indicate that the most important motives for investing in the four countries in question were of the market-seeking category (gaining access to and building a long-term position in the foreign market) followed by efficiency-seeking motives (taking advantage of a skilled labour force and low labour costs). Resource-seeking motives were ranked lowest.

It is noteworthy that none of the empirical studies reported above explicitly used the four types of FDI proposed by Dunning as a framework, although the individual motives included in these studies did seem to represent most of these types of FDI. Also, no attempt has so far been made to link the motives to the modes of FDI. This finding is surprising since the relationship between motives and modes certainly deserves more attention on the part of international business researchers.

\section{Modes of FDI}

The literature on foreign market entry mode is vast. Typically, the modes distinguished and analysed include: exporting, licensing agreements, joint venture and wholly-owned subsidiary or sole venture (Agrawal et al. 1992; Buckley/Casson 1998; Osland et al. 2001). However, fewer studies address specifically the choice between various forms of FDI. In this category some studies identify and analyse three choices that firms undertaking FDI have: green-field investment, acquisition, and joint venture (Kogut/Singh 1988; Woodcock et al. 1994; Nitsch et al. 1996; Bruning et al. 1997). Other studies focus on the dichotomous choice between green-field investment and acquisitions (Caves/Mehra 1986; Zejan 1990; Hennart/Park 1993; Padmanabhan/Cho 1995; Barkema/Vermeulen 1998; Görg 2000; Harzing 2002; Dikova et al. 2003). Sometimes acquisitions are combined with mergers as a distinct entry mode (Bruning et al. 1997) and joint ventures are included in the green-field (start-up) investment category (Barkema/Vermeulen 1998).

Green-field investment is typically defined as an investment of a firm that uses its funds to set up an entirely new economic entity by constructing a new facility. Instead, acquisition consists of using the firm's funds to purchase an already existing operation. This is done by acquiring the controlling equity share in a company which previously owned the operation. A joint venture consists of combining assets in a common and separate organisation by two or more firms which share ownership and control over the use and fruits of these assets (Kogut et. al. 1998; Görg 2000).

Meyer and Estrin (1998/2001) distinguish a special case of acquisition which they call brown-field investment. Under brown-field investment, the foreign investor initially acquires an existing firm but then almost completely replaces plant, equipment, technology, labour and product assortment of that firm. In this way, the acquired firm undergoes deep restructuring and becomes an almost 
totally new operation. These authors have found the brown-field investment construct particularly relevant to FDI in Central and astern Europe.

The authors who have studied the choice between green-field investment and acquisition or between green-field, acquisition and joint venture, point to such determinants of the choice decision as: the entrant's corporate organisation and the structural features of its product market (Caves/Mehra 1986); host country's market size, market growth and level of development (Zejan 1990); firm strategies and target market considerations (Hennart/Park 1993; Harzing 2002); firm's multinational diversity (the diversity of the national markets in which the firm operates) and its product diversity (Barkema/Vermeulen 1998); entry costs and post-entry competition (Görg 2000); investment-, industry, and target country-specific variables (Larimo 2003); cultural distance between home and host countries and attitudes towards uncertainty avoidance (Kogut/Singh 1988); and firm's concern for power, required resource commitment, potential for dissemination risk, and financial concerns related to liquidity and leverage (Bruning et al. 1997).

While many studies addresses the investment mode decisions of MNEs, only three studies were found which deal specifically with the factors influencing the entry mode choice in Central and Eastern Europe. Meyer and Estrin (1998) analyse the determinants of the mode choice decision with reference to the specific investment situation prevailing in CEE. The authors develop a model linking four types of resources (required for the strategic objectives, held by local firms, held by the investor, and available on markets) and two types of costs (transaction costs and costs of adapting and integrating resources) to three modes of FDI (acquisition, green-field and brown-field).

Based on this model, they derive a number of propositions regarding firms' expected mode choice, pointing out that a hybrid option - brown-field operations - should be included in future research on FDI investment modes in CEE. Müller's study, focused of the dichotomous choice between green-field investment and acquisition, offers an explanation why green-field investment is the most common form of FDI in CEE in spite of a general trend towards acquisitions worldwide and the fact that many MNEs enter fast-growing industries in these countries (Müller 2001). This author argues that green-field investment is an optimal choice if the local competitor possesses inferior technology vis-à-vis an investing firm, and that this is typically a market condition met in CEE. The study of Dikova and van Witteloostuijn (2003) covers 10 CEE countries (CEE-8 plus Bulgaria and Romania). It is based on 208 survey responses from EU-15 firms investing in CEE, Dikova and van Witteloostuijn examine the influence of technological intensity, investment relatedness, entry mode experience, international strategy, cultural distance and country risk on entry mode selection. Their results reveal that the most important factors influencing the choice between green-field investment and acquisition in 
CEE are host country risk and experience-based organisational learning. Dikova and van Witteloostuijn argue that the latter factor (organisational learning) plays a unique role in the choice between acquisitions and green-field in the CEE region because of the cultural, political, legal, economic and infrastructurerelated challenges faced by foreign investors.

Although the identified determinants of FDI mode choice encompass a broad spectrum of possibilities, one cannot help noticing the lack of host-government influences on the mode decision. And yet, governments can either provide incentives or disincentives with respect to the choice of individual modes of FDI, depending on these governments' strategic objectives and policies. For example, host governments typically strive to expand the country's industrial capacity and to stimulate local competition, in which case they try to encourage green-field investment and discourage acquisitions.

However, in Poland, until recently and especially at the beginning of the transition process, it was the policy of consecutive governments in power to privatise state-owned firms by encouraging foreign investors to acquire frequently obsolete and inefficiently managed entities rather than allowing for green-field investments. This peculiar approach was motivated by a lack of sufficient domestic capital for such privatisation undertakings. Presently, many foreign firms are very much interested and vying for investing their equity in quite profitable and well run Polish companies (especially in the banking and insurance sectors). Thus the Polish market today is available and attractive for both green-field and acquisition investments.

\section{Research methodology}

The literature review provides specific guidelines as to what variables and relationships should be investigated in this study. The present analysis focuses firstly on the motives for FDI in Poland. In conformity with Dunning's types of FDI, the individual motives were divided into three groups: market seeking, efficiency seeking and resource seeking. In order to preserve clarity and distinctiveness between the types of motives, the fourth group - strategic asset seeking - was not included because of risk of being blurred with the efficiency seeking type of FDI.

As for the modes of FDI, the study focuses on the dichotomous choice between green-field investment and acquisition. This is due to the fact that practically all the firms surveyed were $100 \%$ owned by foreign parents. Also, the information collected did not permit an identification of any brown-field operation in the sense defined by Meyer and Estrin. Finally, the central relationship between the motives for FDI and modes of FDI is investigated - the relationship that has been somewhat neglected in international business studies. 


\section{Sample and the method of data collection}

The research is based on data from seven cases of foreign direct investment made in Poland in the first half of the 1990s. During that period the Polish economy experienced its most dynamic stage of transformation to a market led system. All the analysed cases were from the manufacturing industry and consisted of foreign MNCs subsidiaries located in the western part of Poland. Six of the seven cases concerned wholly-owned subsidiaries.

One was technically a joint venture but with such an ownership structure that for all practical purposes it could be treated as a wholly-owned subsidiary. Geographical convenience for conducting research was the main rationale for such case selection. Geographical concentration of the sample and the resultant geographical homogeneity allowed for minimisation of the influence of the regional differences on the survey responses. On the other hand, some bias cannot be excluded due to the fact that western Poland has always been perceived as the more developed part of the country attracting entrepreneurial and growth oriented firms. Consequently, relatively more firms in this region could have been considered as suitable targets for acquisition by foreign investors. Finally, financial limitations also influenced the scope of this empirical research.

Data were collected by means of personal interviews using a structured questionnaire as the data collection instrument. The interviews were carried out in the first half of the year 2002 in each subsidiary with a member of its management team. The data sets collected were broader in scope than those presented in the present study. In addition to FDI motives and modes, the questionnaire contained more detailed characteristics of the subsidiaries, their post-investment performance assessment, completeness of the value-adding chain managed by the subsidiary, phases of the parent companies' internationalisation process in the Polish market and the level of subsidiary autonomy. Preliminary results of the full-scope study were presented by the authors in a conference paper (Gorynia et al. 2003).

\section{Data analysis}

Due to small sample size the authors could not use any statistical techniques in their analysis of the survey results. Therefore, the research results do not provide grounds for full generalisation of conclusions. Instead, qualitative case analysis is employed, justifying at least hypothesis formulation. In this sense, the present research is essentially of exploratory nature.

Out of several approaches to case-based empirical research identified in related literature (Eisenhart 1989; Ragin et al. 1994; Yin 1993) the choice was made to follow the procedures of comparative case analysis as presented by Ragin and Eisenhart. These procedures consist of three steps. First, within-case analysis is conducted for each case. The task of this analysis is to determine a direction of 
dependencies between the studied variables in a concrete individual case so that a comparative analysis can ensue. The second step is to compare the results of individual cases in order to find cause-effect dependencies between the occurrence or non-occurrence of some variables and the occurrence or nonoccurrence of other variables. Finally, the results of comparisons between cases are contrasted with the results of theoretical inquiry, making it possible to draw hypotheses and conclusions. This way, a generalised theoretical model of dependencies can be constructed. This model may be later subject to further empirical research to test its adequacy. In this sense, the results obtained are of preliminary character.

\section{Analysis of cases}

\section{Within case analysis}

Case 1 This subsidiary was established in 1991. It was a green-field investment. The investor was an Italian company operating in the clothing industry. The following were the most important factors that had led to the selection of the green-field mode of FDI:

- green-field costs were estimated to be lower than those of acquisition, because of the possibility to adjust the scale of operation to the anticipated needs of the market market;

- difficulties associated with the inherited problems of an acquired firm could be avoided, as well as the risk of paying a price premium for the acquired firm;

- possibility to freely choose the investment location;

- anticipated lower production costs in the new facility as compared to an acquired firm.

The most important motives for FDI were as follows:

- market-seeking - to access, sustain and expand markets in the host country; to overcome import barriers; to expand and improve market position;

- efficiency-seeking - lower costs of production and transport, economies of scale and lower wages.

Case 2 The subsidiary was set up in 1991 through acquisition. Its owner is a Dutch investor operating in many branches, including lighting equipment. The main reason justifying acquisition was the opportunity of quick access to the market. The main motive for FDI was the intention to expand and improve the position in the Polish market (market seeking) as well as to cut production costs (efficiency seeking).

Case 3 This subsidiary was established in 1992, also through acquisition. The investor is a German firm operating in the clothing industry. The main motive 
for takeover was the opportunity to start the venture faster. The principal motive for undertaking this FDI was cost efficiency: this was stressed by the firm's management which underlined the desire to take advantage of the relatively low cost but highly qualified labour force in the manufacture of goods destined mainly for export to the German market. The market seeking motive was deemed as immaterial in this case.

Case 4 The next company, and the third case of acquisition, was set up in 1992. Its owner is a German investor operating in the medical instruments sector. The quoted reasons for acquisition (versus green-field) were an intention to enter the Polish market quickly and to take possession of valuable assets of the acquired firm. The motives for FDI were of market and efficiency-seeking nature.

Case 5 This was another green-field investment subsidiary, founded in 1992 and producing machinery and equipment for the glass-making industry. The reasons for choosing the green-field mode were a possibility of free choice of location and anticipated lower costs of production in the new plant than in the case of acquisition. The main motive for undertaking this investment was cost efficiency. The firm indicated that the principal reason for entering the Polish market was a very favourable cost to quality (in the sense of skills and productivity) ratio of the Polish labour force in a specific investment goods industry. Most of the firm's output was also exported to Germany, the home market of the parent company.

Case 6 This case was also a green-field investment, of a German firm, making chocolate products. The green-field mode was chosen because of anticipated lower costs of production in the new plant and because of the opportunity to freely select its location. Efficiency and market-seeking motives were of similar importance for making the investment.

Case 7 The last case under consideration was a subsidiary established in 1991 as an acquisition of a local firm by a Danish company making plastic pipes and pipe fittings. The acquisition mode choice was determined by the opportunity to enter the market quickly and to take possession of valuable assets of the acquired firm. The main motive for FDI was of a market-seeking character, indicated by the firm's executives who also specified a secondary, less important for them motive of lower labour costs than in Denmark.

\section{Cross case analysis}

\section{Motives for FDI}

Only one of the subsidiaries studied can be unambiguously classified as a market seeker in making the investment. Two firms were clear efficiency seekers. Four firms assigned equally high importance to both market and efficiency factors. No firm indicated resource-seeking factors as the main motive 
for undertaking the investment and only two rated these factors as being of low importance, while the other motives (market- and efficiency-seeking) were given high importance. The lack of "pure" resource seekers may be partly attributed to the fact that a major determinant of FDI in Poland, i.e. low labour costs, was bundled in the survey questionnaire together with other predominantly efficiency oriented factors instead of being positioned in the resource category. Another interesting observation is that, contrary to Dunning's (1993) contention that efficiency seeking motives are more likely to be present in follow-up investments, all the subsidiaries under study were established by their parent companies as first time investment in Poland.

\section{Entry modes and their determinants}

In all three cases where the chosen entry mode was green-field investment there was a high degree of unanimity as to the reasons for such a choice. Both the chocolate and clothing manufacturers assigned high importance to the possibility of lowering initial investment outlays through the green-field approach as compared with acquisition, by a better adjustment of the scale of operations and operations strategy to the requirements of the target market. The third firm, producing equipment for the glass industry, assigned only some importance to this factor. The following factors based on the desire to avoid: a problems associated with the acquired company and $b$ the risk of paying a takeover premium, were commonly ranked as high in importance by all three firms. The subsequent reasons investigated were the possibility of freely choosing the investment location and the expected lower manufacturing costs compared to those in the acquisition mode. Both factors, a and $b$, were considered by all three firms as being of high importance.

The host government regulations favouring green-field operations and the lack of Polish firms suitable for acquisition were ranked as being of little importance also by all three companies. The former reason was weak because there were no comprehensive government measures favouring green-field investment. The low ranking of the latter factor indicates that although there were suitable domestic firms which could be targeted for acquisition, still all three companies were firmly convinced that green-field investment was the best way to enter the Polish market.

The most important common determinant in all four cases of the acquisition entry mode was the factor of speed in entering the new market. With the exception of the lighting products firm, the remaining three also attached high importance to the perspective of acquiring valuable assets of the local company, such as brand names, distribution networks and market shares. The plastic pipes and fittings company also quoted the desire to avoid possible cultural, legal and managerial problems which might arise in the green-field mode of entry, but this motive was considered as being of lesser importance. Thus the two dominating 
determinants of the acquisition entry mode - time to market and access to valuable assets - were quite different from those leading to green-field investment.

\section{Entry modes and firm performance}

The analysis of the performance construct as such leads to the conclusion that green-field investment did not guarantee success in the Polish market. This is in contrast to the results of research by Woodcock, Beamish and Makino (1994) who found that green-field investment should demonstrate better performance than acquisition. Only in one of the green-field cases examined were almost all the measures of performance better at the end of the analysed time span than at the beginning. This positive outcome was observed in the investment goods sector (glass industry equipment). The other firms, where most of the performance ratings deteriorated over time, were operating in the consumer goods sector. The effectiveness of the green-field mode of entry appears to be however not so much sector-sensitive as prone to changes in the external environment in a given sector.

The overall influence of the acquisition mode on performance is, on the contrary, quite positive. The performance criterion clearly points to acquisition as being more beneficial than green-field investment. The only negative evolution of performance attributes were observed in the German clothing firm case. A possible explanation, quite common in Poland, lies in excessive (from the subsidiary point of view) transfer of profits abroad. This could have led to lower profitability, worse cooperation with headquarters (subsidiary being antagonised) and the resulting stagnant growth. Further evidence of this being the case is provided by the low autonomy rating of the subsidiary management, signalling high headquarters centralisation and control. In all the other acquisition cases, subsidiary autonomy was rated as being just right.

The surprising findings on entry mode and firm performance should be treated with extreme caution. Besides the possible explanatory factors already identified, taken into account should also be the influence of market conditions on the type of goods being produced (common vs. specialized or investment) and the overall heterogeneity of the analysed sectors. However, above all the said findings which are of a preliminary and qualitative character must be subjected to a rigorous quantitative verification in a further, more extensive and representative statistical analysis, and also after confrontation with existing literature.

\section{FDI motives vs. FDI modes}

It is very difficult to discern any unambiguous relationship between FDI motives and the green-field investment or acquisition entry modes using the existing case material. There are however traces of two, to a certain degree, distinct trends. 
Two out of the three cases where the green-field mode was chosen attached high importance to the market-seeking factors defined in the survey as: getting access to new markets, sustaining and expanding market presence in the host country plus avoiding trade barriers. The second dominant group of motives were efficiency-seeking factors, i.e. lower manufacturing and transport costs, lower costs due to economies of scale plus lower labour costs. The chocolate maker mentioned, in addition, other motives such as defence of existing competitive position and creation of a cost effective supply base, but these factors carried a low importance rating.

Among all the firms that chose the acquisition entry mode, the only common motive were lower costs, as defined above. Three firms gave this motive a high importance rating and only the plastic pipes and fittings firm assigned a low importance mark. The second minimally less common factor was offensive market expansion and improvement of competitive position, falling into the market-seeking category of motives. Other factors, like securing a supply base or defending competitive position, seemed to be incidental. Therefore, within the framework of the existing situation and conditions of the Polish market, the summary conclusion points to the green-field mode as being more suitable for firms which focus on market factors and, at the same time, lower costs. The acquisition mode, on the other hand, will be preferred when the investor is more inclined to act offensively to expand his competitive position, while being mindful of the need to reduce costs.

\section{Discussion of results and hypotheses}

The findings regarding the FDI motives are only partially consistent with the previous empirical studies referred to in the literature review, where market factors assumed higher prominence than efficiency factors. However, these findings are consistent with expectations and observations found in the descriptive and qualitative literature dealing with FDI motives in Central and Eastern Europe (CEE), where the cost-efficiency benefits are pointed out as often as market attractiveness of the region (Hardy 1994).

The shift from market attractiveness to efficiency factors as observed earlier by Dunning is not evident in this study. This is due to the Polish market's FDI absorptive potential connected with market seeking motives still being far from exhausted. But at the same time these motives are positioned to coexist with the efficiency seeking ones especially for sequential investments providing the latter grounds to become more prominent in the future. A certain degree of similarity can be observed in this respect with inward FDI in China.

Almost a total lack of resource-seeking motives can be, at least partially, explained by the sample composition (only manufacturing companies were studied). The inclusion of companies from the extractive sector, for example, 
would have probably led to different results in this respect but such FDI in Poland has so far been rather minimal. Hence clearly this argument reinforces the need to extend the present study, based this time on a sufficiently large sample of foreign MNCs subsidiaries and focused on motives for FDI in CEE. Dunning's classification of FDI motives, as described earlier, could serve as a pertinent organising framework for such research.

In the relationship between green-field investment or acquisition and their determinants, the following preferences were identified. The choice of the green-field investment mode was much more consistently determined across firms than that of acquisition. The firms opting for green-field investments focused on four groups of determinants:

- lower initial investment outlays due to the scale of operations and operations strategy being better adapted to the local market;

- avoidance of problems with acquired companies, including the risk of paying a takeover premium;

- freedom in choosing a suitable investment location;

- expectation of lower manufacturing costs.

The general motives for undertaking FDI in the form of green-field investment were focused on: (a) market-seeking factors perceived as accessing new markets and then sustaining and/or expanding market presence; and (b) efficiencyseeking factors, i.e. lowering costs. Thus the green-field investment mode was seen as being more appropriate for firms classified by Dunning (1993/1998) as market seekers.

Factors affecting acquisition mode demonstrated more variation. Among the many motives quoted for undertaking FDI, only two were common: pursuit of lower costs and offensive expansion and improvement of competitive position. These in turn coincided with and reinforced the two main acquisition determinants: the speed of market entry and the acquisition of such assets as brands and distribution networks plus market shares. Viewed as a summary construct, they came closest to the concept of market and efficiency seekers with more focus being placed on the second category. The importance of efficiency seeking acquisitions can be also derived from the fact that most of those operations were made within the framework of the privatisation process of predominantly mismanaged state owned companies. This factor differentiates such acquisitions from those made in a mature market economy where the strategic asset seeking motive often appears to be more prominent.

The findings and their discussion presented above lead to five research hypotheses shown in Table 2. These hypotheses could be tested in future empirical studies of FDI in Poland and perhaps other countries of the CEE region. 


\section{Conclusions and directions for further research}

Both within-case and cross-case analyses provided important insights into the motives and ways the seven foreign subsidiaries were established in the Polish market. The studied firms, although concentrated in one region of Poland, represented a broad spectrum of manufacturers, ranging from clothing to medical instruments, to glass making equipment.

Table 2. List of hypotheses

\begin{tabular}{|l|}
\hline \multicolumn{1}{c|}{ Motives and determinants } \\
\hline $\begin{array}{l}\text { H1: The main motives for undertaking FDI fall into the market-seeking and efficiency- } \\
\text { seeking categories. }\end{array}$ \\
\hline $\begin{array}{l}\text { H2: Factors that determine the choice of green-field investment are more consistent across } \\
\text { firms than those that determine the choice of the acquisition mode. }\end{array}$ \\
\hline Greenfield versus acquisition \\
\hline $\begin{array}{l}\text { H3: The green-field mode is preferred mostly because of the possibility to adjust the scale of } \\
\text { operations and strategy to the requirements of the target market. }\end{array}$ \\
\hline H4: The acquisition mode is chosen mostly because of the reduced time to enter the market. \\
\hline Motives and modes \\
\hline H5: There is no clear pattern in the relationship between the motives for and modes of FDI. \\
\hline
\end{tabular}

Appendix 1. Summary Characteristics of Cases

\begin{tabular}{|c|c|c|c|c|c|c|c|}
\hline Feature & Case 1 & Case 2 & Case 3 & Case 4 & Case 5 & Case 6 & Case 7 \\
\hline $\begin{array}{l}\text { 1. Pro- } \\
\text { duct line }\end{array}$ & Clothes & $\begin{array}{c}\text { Lighting } \\
\text { equipme } \\
\text { nt }\end{array}$ & $\begin{array}{l}\text { Light } \\
\text { clothes }\end{array}$ & $\begin{array}{c}\text { Surgical } \\
\text { and dental } \\
\text { instruments }\end{array}$ & $\begin{array}{l}\text { Machinery } \\
\text { and equip- } \\
\text { ment for } \\
\text { glass- } \\
\text { making } \\
\text { industry }\end{array}$ & $\begin{array}{l}\text { Chocolate } \\
\text { products }\end{array}$ & $\begin{array}{l}\text { Plastic pipes } \\
\text { and pipe } \\
\text { fittings }\end{array}$ \\
\hline $\begin{array}{l}\text { 2. Year } \\
\text { of } \\
\text { incep- } \\
\text { tion }\end{array}$ & 1991 & 1991 & 1992 & 1992 & 1992 & 1995 & 1991 \\
\hline $\begin{array}{l}\text { 3. Initial } \\
\text { invest- } \\
\text { ment } \\
\text { outlay } \\
\text { (mln } \\
\text { USD) }\end{array}$ & 0.2 & 23.0 & 3.6 & 3.4 & 7.0 & 29.0 & 6.0 \\
\hline $\begin{array}{l}\text { 4. Inves- } \\
\text { tor's } \\
\text { country } \\
\text { of origin }\end{array}$ & Italy & Holland & $\begin{array}{c}\text { German } \\
\mathrm{y}\end{array}$ & Germany & Germany & Germany & Denmark \\
\hline $\begin{array}{l}5 . \text { Entry } \\
\text { mode }\end{array}$ & $\begin{array}{l}\text { Green- } \\
\text { field }\end{array}$ & $\begin{array}{l}\text { Acquisit } \\
\text { ion }\end{array}$ & $\begin{array}{l}\text { Acquisit } \\
\text { ion }\end{array}$ & Acquisition & Green-field & $\begin{array}{l}\text { Green- } \\
\text { field }\end{array}$ & Acquisi-tion \\
\hline
\end{tabular}




\begin{tabular}{|c|c|c|c|c|c|c|c|}
\hline $\begin{array}{l}\text { 6. Main } \\
\text { motives } \\
\text { for FDI }\end{array}$ & $\begin{array}{l}\text { Market } \\
\text { and } \\
\text { efficien- } \\
\text { cy- } \\
\text { seeking }\end{array}$ & $\begin{array}{c}\text { Market } \\
\& \\
\text { Efficien- } \\
\text { cy- } \\
\text { seeking }\end{array}$ & $\begin{array}{c}\text { Efficien } \\
\text { cy- } \\
\text { seeking }\end{array}$ & $\begin{array}{c}\text { Market \& } \\
\text { efficiency- } \\
\text { seeking }\end{array}$ & $\begin{array}{c}\text { Efficiency } \\
\text { seeking }\end{array}$ & $\begin{array}{l}\text { Market \& } \\
\text { efficiency } \\
\text {-seeking }\end{array}$ & $\begin{array}{l}\text { Market- } \\
\text { seeking }\end{array}$ \\
\hline
\end{tabular}

Three of them entered the Polish market through green-field investment and four through acquisition. Most of the investing firms were both market and efficiency seekers. No firm entered the market mainly to seek resources. The predominance of market-seeking and efficiency-seeking motives is fairly consistent with the results of studies of FDI motives in CEE referred to in the literature review. The marginal role of resource seeking motives (excluding Russia and other resource rich former republics of the Soviet Union) in the said review is thus also reconfirmed.

This study, although of a qualitative and exploratory nature, makes several contributions to the research on FDI motives and modes, especially in CEE. The literature review demonstrated that very few studies of this kind have focused on the CEE region and none of them explicitly used the FDI motives framework adopted in this approach. Moreover, hardly any other study has made an attempt to link FDI motives to FDI modes.

\section{References}

Agrawal, S./Ramaswani, S.N. (1992): Choice of Foreign Market Entry Mode: Impact of Ownership, Location, and Internalization Factors. in: Journal of International Business Studies, 23, 1-27.

Ali, S./Mirza, H. (1996): Market-Entry Strategies in Poland. in: Nowak J. (Ed.), Marketing in Central and Eastern Europe. New York, NY: The Haworth Press, 43-62.

Altzinger, W. (1998): Structure and Objectives of Austria's Foreign Direct Investment in Four Adjacent Central European Countries. Paper presented at the $38^{\text {th }}$ Congress of the European regional Science Association, Vienna, Austria, August 28 - September 1.

Barkema, H.G./Vermeulen, F. (1998): International Expansion through Start-up or Acquisition: A Learning Perspective. in: Academy of Management Journal, 41,1, 726.

Behrman, J.N. (1972): The Role of International Companies in Latin America: Autos and Petrochemicals. Lexington, MA: Lexington Books.

Bruning, E.R./Turtle, H.J./Buhr, K. (1997): Characterizing Mode of Entry for Canadian Foreign Direct Investment into the United States: 1980-1989. in: International Journal of Commerce \& Management, 7, 56-80.

Buckley, P.J. (1993): Contemporary Theories of International Direct Investment. in: Revue Economic, 44, 4, 725-736.

Buckley, P.J./Casson, M.C. (1998): Analyzing Foreign Market Entry Strategies: Extending the Internalization Approach. in: Journal of International Business Studies, 29, 3, 539562. 
Caves, R.E./Mehra, S. (1986): Entry of Foreign Multinationals into US Manufacturing Industries. in: Porter M. (Ed.): Competition in Global Industries. Boston, MA: Harvard Business School Press.

Dikova, D./Witteloostuijn, A. (2003): The Influence of Organizational Learning, International Strategy and Transition Costs on Entry Mode Choice in Central and Eastern Europe. in: MNC as a Knowing Organisation. Proceedings of the $29^{\text {th }}$ EIBA Conference, Copenhagen (December).

Dunning, J.H. (1980): Toward an Eclectic Theory of International Production: Some Empirical Tests. in: Journal of International Business Studies, 11, 1, 9-31.

Dunning, J.H. (1981): International Production and the Multinational Enterprise. London: Allen \& Unwin.

Dunning, J.H. (1988): The Eclectic Paradigm of International Production: A Restatement and Some Possible Extensions. Journal of International Business Studies, 19, 1, 1-31.

Dunning, J.H. (1993): Multinational Enterprises and the Global Economy. Harlow, Essex: Addison-Wesley Publication Company.

Dunning, J.H./Rojec, M. (1993): Foreign Privatization in Central and Eastern Europe. Ljubljana, Slovenia: Central and Eastern European Privatization Network.

Dunning, J.H. (1998): Location and the Multinational Enterprise: A Neglected Factor? in: Journal of International Business Studies, 29, 1, 45-66.

Dunning, J.H. (2001): The Key Literature on IB Activities: 1960-2000. in: Rugman A./Brewer T. (Eds): Oxford Handbook of International Business, Oxford: Oxford University Press, Chapter 2.

Durka, B. (2001): Inwestycje zagraniczne w Polsce. Raport roczny, Warszawa: Instytut Koniunktur i Cen Handlu Zagranicznego.

Eisenhardt, K. M. (1989): Building Theories from Case Study Research. in: Academy of Management Review, 14, 4, 532-550.

Fahy, J./Shipley, D./Egan, C./Neale, B.(1998): Motives and Experiences of International Joint Venture Partners in Hungary. in: The Journal of Business \& Industrial Marketing, 13, 2, 155-165.

Görg, H. (2000): Analysing Foreign Market Entry - The Choice between Greenfield Investment and Acquisitions. in: Journal of Economic Studies, 27, 3, 165-181.

Gorynia, M./Nowak, J./Wolniak, S. (2003): Motives and Modes of FDI, Firm Characteristics and Performance: Case Studies of Foreign Subsidiaries in Poland. in: Kaynak E./Harcar T. (eds.): Succeeding in a Turbulent Global Marketplace: Changes, Developments and Challenges. Proceedings of the Twelfth World Business Congress, Vancouver: IMDA.

Hardy, J. (1994): Eastern Promise? Foreign Investment in Poland. European Business Review, 94, 5, 28-37.

Harzing, A.W. (2002): Acquisitions versus Greenfield Investments: International Strategy and Management of Entry Modes. in: Strategic Management Journal, 23, 3, 211-227.

Hennart, J. F./Park, Y.R. (1993): Greenfield vs. Acquisition: The Strategy of Japanese Investors in the United States. in: Management Science, 39, 9, 1054-1070. 
Hennart, J. F. (2001): Theories of the Multinational Enterprise. in: Rugman A./Brewer T. (Eds): Oxford Handbook of International Business, Oxford: Oxford University Press, Chapter 5.

Huberman, A.M./Miles, M. (1994): Data Management and Analysis Method. in: Denzin, N./Lincoln, Y.(eds.): Handbook of Qualitative Research. Thousand Oaks, London, New Delhi: Sage.

Jermakowicz, W.W./Bellas, C.J. (1997): Foreign Direct Investment in Central and Eastern Europe: 1988-1993. in: International Journal of Commerce \& Management, 7, 2, 33 55.

Kim, W.C./Hwang, P. (1992): Global Strategy and Multinationals' Entry Mode Choice. in: Journal of International Business Studies, 23, 1, 29-35.

Kogut, B./Singh, H. (1988): The Effect of National Culture on the Choice of Entry Mode. in: Journal of International Business Studies, 19, 3, 411-432.

Larimo, J. (2003): Forms of investment by Nordic firms in world markets. in: Journal of Business Research, 56, 791-803.

Marinova, S.T./Marinov, M.A. (2003): Motives and Strategies for Foreign Direct Investment in Central and Eastern Europe. in: Marinova, S.T./Marinov, M.A.(eds.): Foreign Direct Investment in Central and Eastern Europe, ASHGATE.

Meyer, K./Estrin, S. (1998): Entry Mode Choice in Emerging Markets: Greenfield, Acquisition, and Brownfield. Working Paper No. 18. Copenhagen: Centre for East European Studies, Copenhagen Business School.

Meyer, K./Estrin, S. (2001): Brownfield Entry into Emerging Markets. in: Journal of International Business Studies, 32, 3, 575-584.

Müller, T. (2001): Analyzing Modes of Foreign Entry: Greenfield Investment versus Acquisition. in: Discussion Paper 2001-01, Department of Economics, University of Munich.

Nitsch, D./Beamish, P./Makino, S. (1996): Entry mode and performance of Japanese FDI in Western Europe. in: Management International Review, 36, 1, 27-35.

Osland, G.E./Taylor, R.C./Zou, S. (2001): Selecting International Modes of Entry and Expansion. in: Marketing Intelligence \& Planning, 19, 3, 153-162.

Padmanabhan, P./Cho, K.R. (1995): Methodological Issues in International Business Studies: the Case of Foreign Establishment Mode Decisions by Multinational Firms. in: International Business Review, 4, 1, 55-73.

PAIiIZ (2003): FDI in Poland, Warsaw: Polish Information \& Foreign Investment Agency.

PAIiIZ (2004): Yearbook 2003, Warsaw: Polish Information \& Foreign Investment Agency.

Ragin, C. C. (1994): Constructing Social in: Research. Thousand Oaks, CA: Pine Forge Press.

Stake, R. (1994): Case Studies. in: Denzin N./Lincoln Y (eds.): Handbook of Qualitative Research. Thousand Oaks, London, New Delhi: Sage.

UNCTAD (2003): World Investment Report 2003. in: FDI Policies for Development: National and International Perspectives. New York and Geneva: United Nations Conference on Trade and Development. 
UNCTAD (2006): World Investment Report 2006. in: FDI from Developing and Transition Economies: Implications for Development. New York and Geneva: United Nations Conference on Trade and Development.

Woodcock, C.P./Beamish, P.W./Makino (1994): Ownership-based Entry Mode Strategies and International Performance. in: Journal of International Business Studies, 25, 2, 253273.

Wolniak, R. (1993): Foreign Direct Investment in Eastern Europe: Investment Modes and Host Country Policy Implications. The Case of Poland. in: Gospodarka polska w okresie przemian, Wydzial Nauk Ekonomicznych, Uniwersytet Warszawski.

Yin, R. (1993): Applications of Case Study Research. Newbury Park, CA, Sage.

Zejan, M.C. (1990): New Venture or Acquisitions: The Choice of Swedish Multinational Enterprises. in: The Journal of Industrial Economics, March, 349-355 